\title{
Evaluation of system of rice intensification (SRI) in farmers fields of Anantapuram district of Andhra Pradesh
}

\author{
C. RADHA KUMARI*, P. LAKSHMI REDDY ${ }^{1}$ AND M. JOHN SUDHEER ${ }^{1}$ \\ Agricultural Research Station, ANANTAPURAM (A.P.) INDIA
}

\begin{abstract}
On-farm demonstrations were conducted to popularize the SRI method of paddy cultivation among the farmers under supervision of DAATT Centre (Extension unit of Acharya N.G. Ranga Agricultural University, Andhra Pradesh), Anantapuram for three years during Kharif, 2007-08 to 2009-10. The comparison was made between SRI method of paddy cultivation and farmers practice with an objective to obtain higher productivity, to reduce the cost of production of paddy and subsequently improve the returns from unit in farmers' fields. The results revealed that during three years of demonstration more number of tillers and panicles $\mathrm{m}^{-2}$ were recorded in SRI compared to farmers practice. SRI recorded higher grain yields compared to farmers practice which was 20.3 per cent higher over farmers practice. Higher gross returns, net returns and benefit cost ratio were also associated with SRI than conventional method of rice cultivation. The cost of cultivation was comparatively lesser in SRI which resulted in gaining an additional net profit of Rs. 15697 ha $^{-1}$ as compared to farmers practice of rice cultivation. In SRI method grain and straw yields were enhanced by 20.3 and 21.0 per cent, respectively over farmers practice.
\end{abstract}

Key Words : SRI, Yield attributes, Grain yield, Economics

View Point Article : Kumari, C. Radha, Reddy, P. Lakshmi and Sudheer, M. John (2015). Evaluation of system of rice intensification (SRl) in farmers fields of Anantapuram district of Andhra Pradesh. Internat. J. agric. Sci., 11 (1): 73-76.

Article History : Received : 12.05.2014; Revised : 09.11.2014; Accepted : 26.11.2014

\footnotetext{
* Author for correspondence

${ }^{1}$ District Agricultural Advisory and Transfer of Technology Center, Acharya N.G. Ranga Agricultural University, ANANTAPURAM (A.P.) INDIA
} 